\title{
Features of pregnancy course in women with chemoresistant tuberculosis (a literature review)
}

\author{
0. M. Raznatovska*A-D,F, O. S. Shalmin ${ }^{\mathrm{E}}$
}

Zaporizhzhia State Medical University, Ukraine

A - research concept and design; B - collection and/or assembly of data; C - data analysis and interpretation; D - writing the article;

$\mathrm{E}$ - critical revision of the article; $\mathrm{F}$ - final approval of the article

Tuberculosis is a global cause of morbidity among women of reproductive age, constituting a serious maternal and perinatal risk in both developed and developing countries. Tuberculosis is the third highest cause of death in women of reproductive age. At the same time, the frequency of diagnosing a specific process in pregnant women and pregnancy in women with tuberculosis is almost the same. Today, against this background, the treatment of chemoresistant tuberculosis (CR-TB) in pregnant women remains controversial.

The purpose. To conduct a review of current literature sources in order to determine the characteristics of gestation in women with CR-TB, which will assist clinicians in the management of such patients.

Results. In pregnant women, extrapulmonary and pulmonary forms of tuberculosis incidence are almost the same. Chest $\mathrm{X}$-ray examination in pregnant women should not be avoided, since the radiation risk for the fetus is insignificant when the abdominal cavity shielding. In women with tuberculosis, childbirth occurs on average at the 38th week of pregnancy, and premature labor is associated with tuberculosis progression. In pregnant women with tuberculosis, the incidence of chorioamnionitis, gestosis, premature birth, anemia, pneumonia, maternal and perinatal mortality is higher than in pregnant women without tuberculosis. Newborns have an increased risk of a premature birth, congenital tuberculosis, intrauterine growth retardation, congenital abnormalities, and distress syndrome. A high frequency of these pathologies in pregnant women and newborns largely depends on tuberculosis progression, chemoresistance of mycobacterium tuberculosis and the adequacy of anti-mycobacterial therapy. Untreated CR-TB is associated with higher maternal mortality, an increased risk of vertical transmission of tuberculosis, spontaneous miscarriage, intrauterine growth restriction, premature birth, increased neonatal mortality. Breastfeeding is possible if there is a sputum culture conversion in mother. The risk of toxic reactions to anti-tuberculosis drugs in breastfed infants is low and may be minimized if a mother with tuberculosis takes medications immediately after breastfeeding. Medical indications for artificial termination of pregnancy at 12-22 weeks' gestation are severe forms of tuberculosis: disseminated, progressive, chemoresistant, with severe complications.

Conclusions. Considering the analysis of the literature, all pregnant women should be prescribed treatment for CR-TB with second-line anti-tuberculosis drugs based on the drug sensitivity test starting from the second trimester (if a patient is HIV-negative or not in a critical state) with the exception of drugs such as amikacin, streptomycin, prothionamide and ethionamide. A timely and adequate anti-mycobacterial therapy is the key to successful pregnancy outcome. Pregnancy follow-up among women with CR-TB should be based on an interdisciplinary approach including a team of physicians such as a tuberculosis specialist, obstetrician, neonatologist, and public health expert.

\section{Особливості перебігу вагітності в жінок, які хворі на хіміорезистентний туберкульоз (огляд Аітератури)}

\section{О. М. Разнатовська, О. С. Шальмін}

Туберкульоз - глобальна причина захворюваності серед жінок репродуктивного віку, що становить серйозну материнську та перинатальну небезпеку як у розвинених країнах, так і країнах, що розвиваються. Туберкульоз посідає 3 місце серед причин смертності жінок репродуктивного віку. При цьому спостерігається майже однакова частота як діагностики специфічного процесу у вагітних, так і вагітності у хворих жінок на туберкульоз. Нині у світі на цьому тлі лікування хіміорезистентного туберкульозу (ХРТБ) у вагітних залишається спірним.

Мета роботи - огляд сучасних літературних джерел щодо встановлення особливостей перебігу вагітності у хворих на ХРТБ, що допоможе клініцистам-практикам у визначенні тактики ведення таких пацієнток.

Результати. У вагітних жінок позалегеневі та легеневі форми туберкульозу виявляють з майже однаковою частотою. Не треба боятися проводити рентгенографрію органів грудної порожнини у вагітних, оскільки під час екранування черевної порожнини ризик опромінення плода $є$ незначним. У хворих жінок на туберкульоз пологи в середньому відбуваються на 38 тижні вагітності, а передчасні пологи пов'язані з прогресуванням туберкульозного процесу. У вагітних, які хворі на туберкульоз, вірогідно частіше порівняно з вагітними без туберкульозу виникають хоріоамніоніт, гестози, передчасні пологи, анемія, пневмонія, висока материнська та перинатальна смертність. У новонароджених є підвищений ризик недоношення, вродженого туберкульозу, внутрішньоутробного обмеження росту плода, вроджених аномалій і дистрес-синдрому. Висока частота розвитку вказаних ризиків у вагітних і новонароджених вірогідно залежить від прогресування туберкульозу, хіміорезистентності мікобактерії туберкульозу та адекватності антимікобактеріальної терапії. Не лікований ХРТБ пов'язують із вищою материнською смертністю, підвищеним ризиком вертикальної передачі туберкульозу, мимовільними викиднями, обмеженням росту плода, передчасними пологами, підвищеною неонатальною смертністю. Грудне вигодовування можливе за відсутності бактеріовиділення в матері. Ризик токсичних реакцій на протитуберкульозні препарати в дітей, які
Key words: tuberculosis, pregnancy.

\section{Zaporozhye}

medical journal 2019; $21(5), 691-696$ DOI: $10.14739 / 2310-1210$ 2019.5.179473

*E-mail: raxnatovskaya@ gmail.com

Ключові слова: туберкульоз, вагітність.

Запорізький медичний журнал. - 2019. T. 21, № 5(116). C. $691-696$ 
перебувають на грудному вигодовуванні, низький, і його можливо звести до мінімуму, якщо мати, хвора на туберкульоз, приймає препарати відразу після годування дитини. Медичними показаннями штучного переривання вагітності, строк якої становить від 12 до 22 тижнів, є тяжкі форми туберкульозу: поширена, прогресуюча, хіміорезистентна, з тяжкими ускладненнями.

Висновки. Враховуючи аналіз літератури, лікування ХРТБ протитуберкульозними препаратами II ряду з урахуванням тесту медикаментозної чутливості необхідно призначати всім вагітним, починаючи з II триместру (за умови, якщо пацієнтка ВІЛ-негативна або не у критичному стані) з виключенням таких препаратів, як амікацин, стрептоміцин, протіонамід та етіонамід. Своєчасна і адекватна антимікобактеріальна терапія $є$ запорукою успішного завершення вагітності. Ведення вагітних жінок, які хворі на ХРТБ, повинно мати міждисциплінарний підхід із командою таких лікарів, як фртизіатр, акушер, неонатолог та експерт з охорони здоров'я.

Ключевые слова:

туберкулез,

беременность.

Запорожский медицинский журнал. - 2019. -

T. 21, № 5(116) - C. $691-696$

\section{Особенности течения беременности у женщин, больных химиорезистентным туберкулезом (обзор митературы)}

\section{Е. Н. Разнатовская, А. С Шальмин}

Туберкулез - глобальная причина заболеваемости среди женщин репродуктивного возраста, что является серьезной материнской и перинатальной опасностью как в развитых, так и в развивающихся странах. Туберкулез стоит на 3 месте среди причин смертности женщин репродуктивного возраста. При этом наблюдается почти одинаковая частота как диагностики специфического процесса у беременных, так и беременности у больных туберкулезом. На этом фоне сегодня в мире лечение химиорезистентного туберкулеза (ХРТБ) у беременных остается спорным.

Цель работы - обзор современных литературных источников для установления особенностей течения беременности у больных ХРТБ, что окажет помощь практикующим клиницистам в тактике ведения таких пациенток.

Результаты. У беременных женщин внелегочные и легочные формы туберкулеза встречаются практически с одинаковой частотой. Не надо бояться проводить рентгенографию органов грудной полости у беременных, поскольку при экранировании брюшной полости риск облучения плода незначительный. У женщин, больных туберкулезом, роды в среднем происходят на 38 неделе беременности, а преждевременные роды связаны с прогрессированием туберкулезного процесса. У беременных, больных туберкулезом, достоверно чаще по сравнению с беременными без туберкулеза возникают хориоамнионит, гестоз, преждевременные роды, анемия, пневмония, высокие материнская и перинатальная смертность. У новорожденных существует повышенный риск недоношенности, врожденного туберкулеза, внутриутробного ограничения роста плода, врожденных аномалий и дистресс-синдрома. Высокая частота развития указанных рисков у беременных и новорожденных достоверно зависит от прогрессирования туберкулеза, химиорезистентности микобактерии туберкулеза и адекватности антимикобактериальной терапии. Не леченный ХРТБ связан с более высокой материнской смертностью, повышенным риском вертикальной передачи туберкулеза, самопроизвольными выкидышами, ограничением роста плода, преждевременными родами, повышенной неонатальной смертностью. Грудное вскармливание возможно при отсутствии бактериовыделения у матери. Риск токсических реакций на противотуберкулезные препараты у детей, находящихся на грудном вскармливании, низкий, и его можно свести к минимуму, если мать, больная туберкулезом, принимает препараты сразу после кормления ребенка. Медицинские показания искусственного прерывания беременности, срок которой составляет от 12 до 22 недель, - тяжелые формы туберкулеза: распространенная, прогрессирующая, химиорезистентная, с тяжелыми осложнениями.

Выводы. Учитывая проведенный анализ литературы, лечение ХРТБ противотуберкулезными препаратами II ряда с учетом теста медикаментозной чувствительности необходимо назначать всем беременным, начиная со II триместра (при условии, что пациентка ВИЧ-отрицательная или не в критическом состоянии) с исключением таких препаратов, как амикацин, стрептомицин, протионамид и этионамид. Своевременная и адекватная антимикобактериальная терапия является залогом успешного завершения беременности. Ведение беременных, больных ХРТБ, должно иметь междисциплинарный подход с командой таких врачей, как фртизиатр, акушер, неонатолог и эксперт здравоохранения.

According to the World Health Organization (WHO) [1], tuberculosis is one of the 10 causes of death of humanity worldwide (in 2017, about 1.3 million people died from tuberculosis, one third of whom were women). As of 2017, there are 558,000 people with rifampicin-resistant tuberculosis (RifTB), which is the most effective first-line drug, registered in the world, and $82 \%$ have multidrug-resistant tuberculosis (MDR-TB). Successful treatment of patients with MDR-TB remains low $-55 \%$ and MDR-TB often ends with palliative care $[2,3]$.

Tuberculosis is a global cause of morbidity among women of reproductive age, constituting a serious maternal and perinatal risk in both developed and developing countries [4-8]. Tuberculosis ranks 3rd among the causes of death in women of reproductive age [4]. At the same time, the frequency of diagnosing a specific process in pregnant women and pregnancy in women with tuberculosis is almost the same. Today, against this background, the treatment of chemoresistant tuberculosis (CR-TB) in pregnant women remains controversial [8-10].

\section{Aim}

To conduct a review of current literature sources in order to determine the characteristics of gestation in women with $\mathrm{CR}-\mathrm{TB}$, which will assist clinicians in the management of such patients.

Thus, M. Knight et al., 2009 [4] indicate that extrapulmonary and pulmonary forms of tuberculosis in pregnant women occur with almost the same frequency, and in the overwhelming majority of cases they are accompanied by nonspecific clinical symptoms. The results of their 
research show that women with tuberculosis give birth on average at the 38th week of pregnancy: in $35 \%$ of cases, women gave birth prior to the 37 th week of pregnancy, in $13 \%$ - prior to the 34 th week (in $6.5 \%$ - such early births are associated with tuberculosis process progression). In $27 \%$ of cases, the delivery was performed through caesarean section, and the reasons for this were not related to the specific process. At the same time, 3 newborns $(9.3 \%)$ died from serious diseases, and among them, congenital anomalies were diagnosed in 1 infant (3.1\%). The researchers recommend using skin tuberculin tests to diagnose tuberculosis in pregnant women (as a screening procedure) and chest $\mathrm{X}$-ray examination, emphasizing that the risk of fetal irradiation is insignificant when shielding the abdominal cavity.

S. Chopra et al., 2017 [5] conducted a 10-year study of pregnancy influence in 50 women with tuberculosis. The authors indicate that the prevalence of tuberculosis in pregnant Indian women is 1.16 cases per 1000 births and in $67 \%$ of cases the specific process is extrapulmonary. It has been established that in pregnant women with tuberculosis, the risk of premature birth is 5 times higher and the risk of intrauterine growth retardation is 3 times higher. The authors recorded $4 \%$ of maternal deaths during this period.

A. El-Messidi et al., 2016 [6] in their retrospective cohort study (2003-2011, USA) determined the incidence trend of tuberculosis during pregnancy and studied the relationship between tuberculosis during pregnancy and complications in the mother and her fetus. The authors determined a significant increase in the incidence of tuberculosis in pregnant women from 1.92 to 4.06 cases per 10,000 births. At the same time, extrapulmonary forms of tuberculosis also prevailed. It has been definitely determined that pregnant women with tuberculosis were more likely to have chorioamnionitis, preterm delivery, postpartum anemia, pneumonia and acute respiratory distress syndrome in the newborn than pregnant women without tuberculosis. The researchers also emphasized the increased incidence of maternal mortality and a high incidence of congenital anomalies in newborns.

Researchers in South Asia [7] found that maternal tuberculosis is associated with an increased risk of a small-for-gestational-age birth, preterm birth, low birth weight infants and high perinatal mortality. The occurrence of these risks largely depends on the progression of tuberculosis, chemoresistance of mycobacterium tuberculosis (MBT) and adequacy of antimycobacterial therapy (AMBT). It has been established that maternal and obstetric complications most often develop in pregnant women, when tuberculosis is diagnosed in the 3rd trimester and the occurrence of preterm birth is 9 times higher. It was also pointed out that since abdominal tuberculosis in pregnant women is very difficult to diagnose because of its symptoms are masked by the pregnancy itself and the enlarged uterus, it has extremely unfavorable maternal and perinatal prognosis. The authors noted that very/extremely low birth weight was associated with fetal growth restriction in a pregnant woman with tuberculosis.

According to the literature [11], high incidence of severe premature birth and perinatal mortality is determined among pregnant women with tuberculosis who started treatment in the 3rd trimester.

Undoubtedly, a complete course of AMBT that is similar to treatment for non-pregnant women exists to achieve a successful pregnancy outcome in a woman with active TB. According to N. Jana et al., 2012 [7], the risk of toxic reactions to AMBT in breastfed infants is low and may be minimized if the mother with tuberculosis takes medications immediately after breastfeeding. The authors also draw attention to the fact that the diagnosis of tuberculosis during pregnancy is often delayed due to the same symptoms of the specific process and pregnancy overlapping and physician reluctance to perform chest $\mathrm{X}$-ray examination in pregnant women. At the same time, they point out that perinatal mortality among women with tuberculosis is 5 times higher.

Harbuziuk V. V. and Polova S. P. (2016) [12] investigated the features of gestation course in women with drug-susceptible tuberculosis. Thus, they found that the significant factors leading to pregnancy complications in women with tuberculosis were the following pathologies: endocrine $(46.2 \%)$, gynecological $(36.5 \%)$, somatic and infectious $(75 \%)$. It was found that complications in women with tuberculosis during childbirth occur 2.3 times more often than in somatically healthy pregnant women, and in those with destructive tuberculosis, this figure increases 4.8 times. The data obtained by these authors also indicated significant intrauterine growth retardation with signs of antenatal hypotrophy. They also found that a serious cause of the pregnancy complications in women with tuberculosis is anemia which occurs in $94.2 \%$ of cases. They proved that obstetric complications in this category of patients are caused by morphological changes in the chorionic villi [13].

Mathad J. S. and A. Gupta (2012) [8] conducted a study of pregnancy and postpartum period influence on tuberculosis progression. As for the management of active tuberculosis in pregnant women and in the postpartum period, the authors distinguish the following. Breastfeeding of newborns is possible for MBT sputum smear negative women and in drug-susceptible form of tuberculosis. In terms of breastfeeding in women with CR-TB, the authors caution in this regard, since the data on the effect of second-line anti-tuberculosis drugs concentration in breast milk on newborns are insufficient.

J. Sugarman et al., 2010 [9] indicate that the risk of premature birth is twice higher in pregnant women with tuberculosis, low birth weight as well as intrauterine growth retardation and an increase in the incidence of perinatal mortality are 6 times increased. These authors also indicate that chest $\mathrm{X}$-ray examination involves minimal risk to a fetus, and therefore should be used in pregnant women. It is also emphasized that the treatment of a specific process for pregnant women with tuberculosis should be the same as for non-pregnant patients with tuberculosis.

Thus, E. Palacios et al., 2009 [10] carried out a retrospective study of the treatment results and pregnancy outcomes in a group of women who received treatment for pulmonary CR-TB in Peru. Regarding the pulmonary CRTB, the authors found that $61 \%$ of cases were cured, $13 \%$ of women died, $13 \%$ refused treatment, and AMBT failure was determined in $5 \%$ of cases. Regarding the course of pregnancy, it was found that in $10.5 \%$ of cases, women experienced a clinical worsening of the specific process during pregnancy, $13.1 \%$ of pregnancies resulted in miscarriages, pregnancy complications were determined in $21 \%$ of cases, 1 infant (2.6\%) was stillborn, 1 infant 
(2.6 \%) was born prematurely, 3 infants $(7.8 \%)$ were born with low birth weight, and fetal distress syndrome was diagnosed in 1 infant $(2.6 \%)$. None of the newborns was diagnosed with the teratogenic effect of anti-tuberculosis drugs which were administered to the mothers during pregnancy. It was established that effective treatment of tuberculosis in early pregnancy significantly reduces perinatal morbidity, and inadequate treatment of the specific process significantly increases both the risk of treatment failure and the enhancement of MBT resistance to anti-tuberculosis drugs. It was revealed that inadequate and uncontrolled AMBT may lead to fetal demise, congenital tuberculosis and postpartum infection of a newborn. As a result of the literature analysis, the researchers identified the following options for the management of pregnant women with CR-TB: withdrawal of CR-TB treatment, termination of pregnancy or continuation of CR-TB treatment during pregnancy. The authors themselves express support for complete course of adequate AMBT in pregnant women with pulmonary CR-TB without pregnancy interruption under medical supervision.

The article of M. Ünlü et al., 2015 [14] provides a case of severe MDR-TB in a pregnant woman who received complete AMBT throughout the pregnancy and gave birth to a healthy child. At the same time, during the 8-month follow-up, the child did not exhibit any complications and there were no manifestations of second-line anti-tuberculosis drugs teratogenicity. On this basis, the authors strongly recommend not interrupting pregnancy in women with MDR-TB and administering a complete course of AMBT during pregnancy.

In their study, P. Tabarsi et al., 2011 [15] observed 5 women with pulmonary MDR-TB, who became pregnant during treatment with second-line anti-TB drugs according to the drug sensitivity test. The results of their research showed that all women recovered and gave birth to healthy children. In this case, complications were observed neither during pregnancy nor during childbirth. Adverse reactions to anti-TB drugs were determined neither in the parturients nor in the newborns. Therefore, the authors also recommended a complete course of AMBT for MDR-TB during pregnancy indicating its safety and efficacy during pregnancy.

Deependra Kumar Rai claims in his work (2016) [16] that untreated tuberculosis poses a great risk to both a pregnant woman and a fetus. At the same time, the author points out that the treatment of drug-susceptible specific process should be prescribed according to the same scheme used for non-pregnant women with tuberculosis, with the exception of streptomycin. As for MDR-TB, the researcher recommends to terminate the pregnancy, since most of second-line anti-TB drugs are teratogenic.

In Ukraine, medical indications for artificial termination of pregnancy at 12-22 weeks' gestation are severe forms of tuberculosis: disseminated, progressive, chemoresistant, with severe complications (except for nervous system and acute meningeal tuberculosis, miliary tuberculosis) [17].

O. S. Hurskyi \& S. P. Rolova (2013) [18] conducted a study of clinical and morphological disorders of the placental complex in 26 cases of artificial pregnancy termination for medical reasons in women with drug-susceptible newly diagnosed tuberculosis (NDTB) at 9-16 weeks' gestation. The researchers found that NDTB contributes to pathological course of pregnancy in women, causes threatened miscarriage and the risk of perinatal mortality.
S. P. Polova \& V. V. Harbuziuk (2013) [19] conducted a study of the uteroplacental area structure during preterm birth in pregnant women with pulmonary tuberculosis. It was established that in pregnant women with tuberculosis, preterm birth was caused by morphological changes in the chorionic villi. At the same time, an ischemia of the placental intervillous space caused an impaired chorionic villi maturation and damage to the trophoblasts and chorionic villi as a result of uteroplacental inflammatory process in tuberculosis.

Yakovlev A. A. et. al., 2012 [20], studying a combined course of tuberculosis (in $80.5 \%$ of cases - drug-susceptible tuberculosis, in $19.5 \%$ - drug-resistant tuberculosis) and pregnancy in Omsk (the Russian Federation), found that tuberculosis caused $62.8 \%$ of pregnancy complications cases (preeclampsia, anemia), $100 \%$ of complications in the postpartum period (decrease in contractile activity of the uterus, bloody vaginal discharge, postpartum endometritis), $49.3 \%$ of complications in the fetus and newborns (low birth weight and neonatal pathology in $100 \%$ ). Coincidently, the tuberculosis process progression was diagnosed in $31.7 \%$ of pregnant women and in $63.3 \%$ of women in the postpartum period (the effectiveness of treatment for tuberculosis in the postpartum period was $27.3 \%$ ). It was also established that tuberculosis had a favorable course after pregnancy termination in the early stages in the overwhelming number of cases.

According to the scientific research of V. V. Harbuziuk (2019) [21], the incidence of preterm birth in women with tuberculosis is $63.1 \%$, which is significantly determined by the specific process activity and form (the risk of developing threatened premature birth was increased by 12.4 times in disseminated tuberculosis, by 7.2 times in fibrous-cavernous tuberculosis and by 4 times in focal tuberculosis) in $60.5 \%$ of cases. These factors are accompanied by substantial changes in the hormonal function and microcirculation of the fetoplacental complex, persistence of pathogenic and conditionally pathogenic microorganisms in the parturient canal, an increase in immunodeficiency, a decrease in resistance to stress and an increase in anxiety.

Rohilla M. et al., 2016 [22] studying the course and treatment of MDR-TB in pregnant women also indicate insufficient global experience in the use of second-line anti-TB drugs in pregnant women, which have a significant teratogenic effect, greatly complicating this issue. However, on the other hand, it is impossible not to treat MDR-TB. These researchers presented 2 clinical cases from their own observations: in the first case, a pregnant woman received second-line anti-tuberculosis drugs throughout her pregnancy and in the second case a pregnant woman started treatment in the last trimester. Both women gave birth to healthy children. A6-month follow-up of both mothers and newborns revealed no complications and no adverse reactions. The authors emphasized that the management of pregnant women with MDR-TB should be based on an interdisciplinary approach including a team of physicians such as a pulmonologist (tuberculosis specialist), obstetrician, neonatologist, and public health expert. It was recommended that AMBT should be postponed until the second trimester in such patients in order to prevent the teratogenic effects of anti-TB drugs (provided that a patient is HIV-negative or not in critical condition). 
According to A. Dudnyk and O. Pavelchuk (2016) [23], it was established that pregnant women with MDR-TB exhibit a higher incidence of unfavorable treatment and delivery outcomes compared to pregnant women with drug-susceptible tuberculosis (control group). Despite the fact that $100 \%$ of pregnant women with drug-susceptible tuberculosis recovered, in women with MDR-TB, the recovery and mortality rates were $40 \%$ each. Twenty percent of women with MDR-TB had an abortion (10\% had a miscarriage and $10 \%$ had a pregnancy termination for medical reasons). With higher incidence in pregnant women with MDR-TB, diagnosis of pregnancy complications (30\% vs. $6.6 \%$ ) and adverse reactions to anti-TB drugs (60\% vs. $33.3 \%$ ) were observed. The situation being what it is, $60 \%$ patients with MDR-TB who received second-line anti-TB drugs gave birth to healthy children, $10 \%$ had a newborn with low birth weight and $10 \%$ of infants were tuberculosis/HIV co-infected.

Laniado-Laborín R. et al., 2018 [24] in their article also presented a clinical case of their own observation of MDR-TB course and treatment in a pregnant woman. The authors indicated that the woman completed a full-course of second-line AMBT and gave birth to a healthy child. Thus the treatment of MDR-TB in the pregnant woman was favorable for her and her newborn.

Prasad R. et al., 2015 [25] indicate that, given the teratogenicity of second-line anti-TB drugs in pregnant women with MDR-TB, it is necessary to consider all risks and benefits of the therapy. At the same time, researchers also emphasize that the MDR-TB treatment should begin with the 2nd trimester of pregnancy. The choice of treatment should be based mainly on the MDR-TB severity, and termination of pregnancy should be performed if there is a risk to mother's life. Medical indications for termination of pregnancy are up to 20 weeks due to the possible serious risks for both a mother and fetus.

According to the latest WHO recommendation (2019) [1], such anti-TB drugs as amikacin, streptomycin, prothionamide and ethionamide are contraindicated during pregnancy. Information on the safety of bedaquiline and delamanid during pregnancy and breastfeeding is scarce. Therefore, in these cases, WHO recommends to carefully record the results of treatment, pregnancy and postpartum period while administering bedaquiline and delamanid. Congenital anomalies should be documented to assist in further recommendations for MDR-TB treatment during pregnancy.

\section{Discussion}

1. In pregnant women, incidence of extrapulmonary and pulmonary forms of tuberculosis is almost the same.

2. Chest X-ray examination in pregnant women should not be avoided, since the radiation risk for the fetus is insignificant when the abdominal cavity shielding.

3. In women with tuberculosis, childbirth occurs on average at the 38th week of pregnancy, and premature labor is associated with tuberculosis progression.

4. In pregnant women with tuberculosis, the incidence of chorioamnionitis, gestosis, premature birth, anemia, pneumonia, maternal and perinatal mortality is higher than in pregnant women without tuberculosis.
5. Newborns have an increased risk of premature birth, congenital tuberculosis, intrauterine growth retardation, congenital abnormalities, and distress syndrome.

6. A high frequency of these risks in pregnant women and newborns largely depends on tuberculosis progression, chemoresistance of mycobacterium tuberculosis and the adequacy of anti-mycobacterial therapy.

7. Untreated chemoresistant tuberculosis is associated with higher maternal mortality, an increased risk of vertical transmission of tuberculosis, spontaneous miscarriage, intrauterine growth restriction, premature birth, increased neonatal mortality.

8. Breastfeeding is possible if there is a sputum culture conversion in mother. The risk of toxic reactions to anti-tuberculosis drugs in breastfed infants is low and may be minimized if a mother with tuberculosis takes medications immediately after breastfeeding.

9. Medical indications for artificial termination of pregnancy at 12-22 weeks' gestation are severe forms of tuberculosis: disseminated, progressive, chemoresistant, with severe complications.

\section{Conclusions}

Considering the analysis of the literature, all pregnant women should be prescribed treatment for chemoresistant tuberculosis with second-line anti-tuberculosis drugs based on the drug sensitivity test starting from the second trimester (if a patient is HIV-negative or not in a critical state) with the exception of drugs such as amikacin, streptomycin, prothionamide and ethionamide. A timely and adequate anti-mycobacterial therapy is the key to successful pregnancy outcome. Pregnancy follow-up among women with chemoresistant tuberculosis should be based on an interdisciplinary approach including a team of physicians such as a tuberculosis specialist, obstetrician, neonatologist, and public health expert.

Prospects for further research. To present clinical cases of own observations of pregnancy course in women with CR-TB.

Conflicts of interest: authors have no conflict of interest to declare. Конфлікт інтересів: віАсутній.

Надійшла Ао редакції / Received: 26.06.2019

Після Аоопрацювання / Revised: 02.07.2019

Прийнято Ао Аруку / Accepted: 04.07.2019

Information about authors:

Raznatovska 0. M., MD, PhD, DSc, Professor of the Department of Phthisiology and Pulmonology, Zaporizhzhia State Medical University, Ukraine.

ORCID ID: 0000-0003-2252-9063

Shalmin 0. S., MD, PhD, DSc, Professor, Head of the Department of Phthisiology and Pulmonology, Zaporizhzhia State Medical University, Ukraine.

Відомості про авторів:

Разнатовська О. М., А-р меА. наук, професор каф. фтизіатрії і пульмонології, Запорізький державний медичний університет, Україна.

Шальмін О. С., А-р меА. наук, професор, зав. каф. фтизіатрії і пульмонології, Запорізький державний медичний університет, Україна. 


\section{Сведения об авторах:}

Разнатовская Е. Н., А-р меА. наук, профессор каф. фтизиатрии и пульмонологии, Запорожский государственный меАицинский университет, Украина.

Шальмин А. С., А-р меА. наук, профессор, зав. каф. фтизиатрии и пульмонологии, Запорожский госуАарственный меАицинский университет, Украина.

\section{References}

[1] World Health Organization (2019). Global Tuberculosis Report 2018 Geneva.

[2] Raznatovskaya, E. N., \& Khudyakov, G. V. (2017). Assessment of palliative patients with chemoresistance pulmonary tuberculosis life quality in the conditions of specialized hospital at the corrective labour colony. Zaporozhye medical journal, 19, 3(102), 358-362. doi: 10.14739/23101210.2017.3.100936 [in Ukrainian].

[3] Raznatovska, O. M., \& Khudiakov, G. V. (2018). Factors of chemoresistant pulmonary tuberculosis progression in patients receiving palliative treatment. Zaporozhye medical journal, 20, 3(108), 388-391. doi: 10.14739/2310-1210.2018.3.130829 [in Ukrainian]

[4] Knight, M., Kurinczuk, J. J., Nelson-Piercy, C., Spark, P., \& Brocklehurst, P. (2009). Tuberculosis in pregnancy in the UK. BJOG, 116 584-588. doi: 10.1111/j.1471-0528.2008.02097.x

[5] Chopra, S., Siwatch, S., Aggarwal, N., Sikka, P., \& Suri, V. (2017), Pregnancy outcomes in women with tuberculosis: a 10-year experience from an Indian tertiary care hospital. Tropical Doctor, 47(2), 104 doi: $10.1177 / 0049475516665765$

[6] El-Messidi, A., Czuzoj-Shulman, N., Spence, A. R., \& Abenhaim, H. A. (2016). Medical and obstetric outcomes among pregnant women with tuberculosis: a population-based study of 7,8 million births. American Journal of Obstetrics and Gynecology, 215(6), 797-799. doi: 10.1016/j. ajog.2016.08.009

[7] Jana, N., Barik, S., Arora, N., \& Kumarendu Singh, A. (2012). Tuberculosis in pregnancy: The challenges for South Asian countrie. Journal of Obstetrics and Gynaecology Research, 38(9), 1125-1136. doi: 10.1111/j.1447-0756.2012.01856.x

[8] Mathad, J. S. \& Gupta, A. (2012). Tuberculosis in Pregnant and Postpartum Women: Epidemiology, Management, and Research Gaps. Clin Infect Dis, 55(11), 1532-1549. doi: 10.1093/cid/cis732

[9] Sugarman, J., Colvin, Ch., Moran, A. C., \& Oxlade, O. (2014). Tuberculosis in pregnancy: an estimate of the global burden of disease. Lancet Glob Health, 2(12), e710-716. doi: 10.1016/S2214-109X(14)70330-4

[10] Palacios, E., Dallman, R., Muñoz, M., Hurtado, R., Chalco, K., Guerra, D., Mestanza, L., et al. (2009). Drug-resistant tuberculosis and pregnancy: Treatment outcomes of 38 cases in Lima, Peru. Clin Infect Dis, 48(10), 1413-1419. doi: 10.1086/598191

[11] UNICEF. India statistics. [Cited 27 Jul 2010.]. Retrieved from http:// www.unicef.org/infobycountry/india_statistics.html.

[12] Harbuziuk, V. V., \& Polova, S. P. (2016). Vahitnisti tuberkuloz: perspektyvy naukovoho poshuku [Pregnancy and tuberculosis: prospects for scientific research]. Vrachebnoe delo, 3-4(1138), 39-44. [in Ukrainian].

[13] Harbuziuk, V. V., \& Polova, S. P. (2014). Patomorfolohichna diahnostyka peredchasnykh polohiv u zhinok, khvorykh na tuberkuloz lehen [Pathomorphological diagnostics of preterm labor in women with pulmonary tuberculosis]. Pediatriia, akusherstvo ta hinekolohiia, 462(2), 69-71. [in Ukrainian].

[14] Ünlü, M., Çimen, P., Arı, G., \& Şevket Dereli, M. (2015). A Successfully Treated Severe Case of Extensively Drug-Resistant Tuberculosis During Pregnancy. Respiratory Case Reports, 4(1), 67-71.

[15] Tabarsi, P., Moradi, A., Baghaei, P., Mariani, M., Shamaei, M., Mansouri, N., et al. (2011). Standardised second-line treatment of multidrug-resistant tuberculosis during pregnancy. Int J Tuberc Lung Dis, 15(4), 547-550. doi: 10.5588/ijtld. 10.0140

[16] Deependra Kumar Rai. (2016). Tuberculosis in pregnancy. Eastern J Medical Sciences, 1(2), 42-45

[17] Postanova Kabinetu Ministriv Ukrainy «Pro realizatsiiu statti 281 Cyvilnoho kodeksu Ukrainy» vid 15 liutoho 2006 r. №144. [Cabinet of Ministers of Ukraine Resolution On the implementation of Article 281 of the Civil Code of Ukraine from February 15, 2006 No. 144]. Kyiv. [in Ukrainian].

[18] Hurskyy, O. S., \& Polyova, S. P. (2013). Pereryvannia vahitnosti u zhinok, khvoryh na tuberkuloz lehen [Therapeutic abortion in women with pulmonary tuberculosis]. Dosiahnennia biolohii ta medytsyny, 1(21) 34-36. [in Ukrainian].

[19] Polova, S. P., \& Harbuzyuk, V. V. (2013). Struktura matkovo-platsentarnoi dilianky pry peredchasnykh polohakh u vahitnykh, khvorykh na tuberkuloz [Structure of the uterus-placental area at preterm birth in pregnant women with tuberculosis]. Klinichna ta eksperymentalna patolohiia, 17(4), 103-105. [in Ukrainian].
[20] Yakovleva, A. A., Mordyk, A. V., Zhukova, N. V., Antropova, V. V., \& Nikolaeva, I. I. (2012). Analiz techeniya i iskhodov tuberkuleza beremennosti pri ikh sochetanii u pacientok reproduktivnogo vozrasta [Analyses of pregnancy with tuberculosis course and outcomes in reproductive age patients]. Sibirskoe medicinskoe obozrenie Retrieved from https://cyberleninka.ru/article/n/analiz-techeniya-i-ishodov-tuberkuleza-i-beremennosti-pri-ih-sochetanii-u-patsientok-reproduktivnogo-vozrasta [in Russian].

[21] Harbuzyuk, V. V. (2019). Obgruntuvannia profilaktyky ta likuvalnoi taktyky pry peredchasnykh polohakh u zhinok, khvorykh na tuberkuloz lehen [Substantiation of prophylaxis and curative tactics during preterm labor in women with pulmonary tuberculosis]. Kyiv. [in Ukrainian].

[22] Rohilla, M., Joshi, B., Jain, V., Kalra, J., \& Prasad, G. R. V. (2016). Multidrug-Resistant Tuberculosis during Pregnancy: Two Case Reports and Review of the Literature. Case Rep Obstet Gynecol. doi: 10.1155/2016/1536281

[23] Dudnyk, A., \& Pavel'chuk, O. (2016). Multidrug-resistant tuberculosis in pregnant women: Treatment and birth outcomes. European Respiratory Journal, 48. doi: 10.1183/13993003.congress-2016.PA1912

[24] Laniado-Laborín, R., Carrera-López, K., \& Hernández-Pérez, A. (2018). Unexpected Pregnancy during Treatment of Multidrug-resistant Tuberculosis. Turk Thorac J, 19. doi: 10.5152/TurkThoracJ.2018.17062

[25] Prasad, R., Gupta, N., Singh, A., \& Gupta, P. (2015). Multidrug-resistan and extensively drug-resistant tuberculosis (M/XDR-TB): management in special situations. International $J$ of Medical Science and Public Health, 4(12), 1626-1633. 